\title{
Hagnýting jarðvarma til nýsköpunar
}

\author{
Eypór Ívar Jónsson ${ }^{1}$
}

\begin{abstract}
Ágrip
Tilgangur greinarinnar er að rannsaka hvernig afmarkaður jarðvarmaklasi getur haft áhrif á próun nýsköpunar hjá fyrirtækjum. Gerð er raundæmisrannsókn og prjú raundæmi skoðuð; ORF Líftækni, Carbon Recycling International og Stolt Sea Farm Iceland. Ennfremur er leitað svara við pví hjá fyrirtækjunum; i. í hverju nýsköpunin felst, ii. hver áhrif jarðvarmaklasans eru á nýsköpun fyrirtækja og iii. hver áhrif notkun jarðvarmans hefur á nýsköpun fyrirtækja. Niðurstaðan er að pað er margt sem bendir til pess að afmarkaður jarðvarmaklasi geti haft áhrif á próun nýsköpunar hjá fyrirtækjum. Í peim premur raundæmum sem skoðuð eru í pessari rannsókn hefur nýsköpun eitthvað að sækja í jarðvarmaklasann. •að mætti jafnvel færa rök fyrir pví að pessi fyrirtæki hefðu ekki farið pá leið í nýsköpun sem raun ber vitni ef pau hefðu ekki verið hluti af sérhæfðum jarðvarmaklasa. Rannsóknin bendir til pess að ástæðan felist fyrst og fremst í próun á sérhæfðri fjölhæfni og samansöfnunar pekkingar. Раð eru hins vegar færri vísbendingar um að tengslanet klasans skipti máli. Má segja að pað sé talsvert í mótsögn við pað sem fræðimenn telja vera meginávinningur klasa.
\end{abstract}

\section{Abstract}

The purpose of the article is to research how specific geothermal cluster can affect the development of innovation in firms. A multiple case study approach is used with three cases; Orf, Carbon Recycling International and Stolt Sea Farm Iceland. Furthermore, the research seeks to answer; i. what kind of innovation is used, ii. what impact geothermal has on innovation, and, iii. what impact the usage of geothermal has on innovation of the firms. The conclusion is that there is evidence which implies that a specific geothermal cluster can affect innovation development in firms. In the three cases which are used in the research, innovation is something to build on in the geothermal cluster. It could be argued that the companies would not have taken the same path in innovation as is evident if they would not have been part of the specific geothermal cluster. The research implies that the main reason for innovation is first and foremost development of specific capabilities and knowledge accumulation. There is, however, less evidence for the importance of networking within the cluster. It could be said that the conslusion contradicts what scholars have argued for as the main benefits of clusters.

JEL flokkun: M11, O13, O32, Q42

Lykilorð: Notendadrifin nýsköpun, jarðvarmi, notorka, klasar,

1 Eypór Ívar Jónsson er lektor við Copenhagen Business School. Netfang: ej.si@cbs.dk.

This work is licensed under a Creative Commons Attribution 4.0 License.

DOI: https://doi.org/10.24122/tve.a.2020.17.1.2

(c) Tímarit um viðskipti og efnahagsmál 
Keywords: User-driven innovation, geothermal energy, cluster, knowledeg and learning

\section{Exploiting geothermal energy for innovation}

\section{Inngangur}

Á undanförnum árum hafa allmörg fyrirtæki verið stofnuð á Suðurnesjum sem hagnýta jarðvarma. Bláa lónið er langstærst og pekktast peirra, eitt arðbærasta fyrirtæki landsins og er nánast orðið táknmynd fyrir pá dulúð sem gerir Ísland að eftirsóknarverðum áfangastað. Sem dæmi um önnur fyrirtæki má nefna Haustak en hjá fyrirtækinu starfa um fimmtíu manns en framleiðsla á silungi hefur vaxið úr 1,5 púsund tonnum árið 2010 í tæp 5 púsund tonn árið 2018 (Hagstofa Íslands, 2019).

Ytri aðstæður hafa spilað hlutverk í próuninni en fjöldi ferðamanna hefur haft mikil áhrif á t.d. uppbygginu Bláa lónsins á svæðinu. Pessi nýju fyrirtæki hefðu hugsanlega verið meira áberandi hluti peirrar svæðislegu enduruppbyggingar sem pörf var á eftir að herinn fór með tilheyrandi röskun ef ekki væri fyrir uppsveiflu ferðapjónustunnar. Talsvert hefur verið unnið í að kortleggja jarðvarmasvæði Íslands en svæðið á suðurnesjum hefur annars vegar verið skoðað út frá uppbyggingu jarðvarmaklasa á Íslandi (Hákon Gunnarsson og Póra Margrét Porgeirsdótir, 2011) og hins vegar uppbyggingu Auðlindagarðs (Gísli Hauksson, 2015).

Jarðvarmaklasinn var kortlagður í samstarfi við Michal Porter og Christian Ketel árið 2010 í samvinnu við ráðgjafarfyrirtækið Gekon. Um 58 aðilar tóku pátt í samstarfi um að kortleggja Ísland og jarðvarmann, sem var stýrt undir merkjum jarðvarmaklasans (Hákon Gunnarsson og Póra Margrét Porgeirsdótir, 2011). Auðlindagarðurinn er svæðisbundin klasahugmynd sem var sett fram og próuð af hugmyndasmiðnum Alberti Albertssyni í byrjun tuttugustu aldarinnar undir slagorðinu: Samfélag án sóunar. Hugmyndin var að hægt væri að nýta auðlindastraum frá jarðvarmaverum HS Orku til pess próa sjálfbærar viðskiptalausnir. Saga svæðisins sem jarðhitasvæði er hins vegar lengri og má rekja til 1755 pegar fyrstu tilraunaboranir á jarðvarmasvæðum voru gerðar (Auðlindagarðurinn, 2019).

Lykilpáttur í próun jarðvarmaklasans og Auðlindagarðsins eru fjölpættir nýtingarmöguleikar jarðvarmans. Vaxtartækifærin jarðvarmaklasans sem samfélag jarðvarmaklasans lagði áherslu á voru að flytja út rafmagn í gegnum streng, að laða að erlenda orkuháða starfsemi til landsins eða að flytja út íslenska pjónustu og pekkingu á sviði jarðvarma (Hákon Gunnarsson og Póra Margrét Porgeirsdótir, 2011). Pað sem hins vegar var lítil rætt um var nýsköpun sem vaxtartækifæri, nýsköpun sem myndi byggja að einhverju leyti á notkun jarðvarmans með beinum eða óbeinum hætti. Bláa lónið er dæmi um einstaka nýsköpun par sem notkun jarðvarmans er með margvíslegum hætti en verðmætasköpunin felst ekki hvað síst í ímyndinni sem sköpuð hefur verið í kringum Bláa lónið og snýr að upplifun viðskiptavina lónsins. Bláa lónið hefur pannig skapað góða fjárhagslega afkomu síðustu árin en félagið tók á móti 1,3 milljón gestum, velti um 12,3 milljörðum og skilaði 3,7 milljörðum í hagnað árið 2017 (Ársskýrsla Bláa lónsins, 2018).

Vaxtartækifæri sem felur í sér nýsköpun sem myndi byggja að einhverju leyti á notkun jarðvarmans með beinum eða óbeinum hætti er pess vegna áhugavert rannsóknarefni. Petta viðfangsefni hefur verið lítið rannsakað á Íslandi með tilliti til peirrar auðlindar sem jarðvarminn er. Útgangspunktur rannsóknarinnar er orka jarðvarmans og bein og óbein áhrif á nýsköpun sem tækifæri fyrir fyrirtæki að nýta sér sem vaxtartækifæri. Rannsóknarspurningin er: Hvernig getur afmarkaður jarðvarmaklasi haft áhrif á próun nýsköpunar hjá fyrirtækjum sem tengjast klasanum. Ennfremur er leitað svara við pví; i. í hverju nýsköpunin felst, ii. hver áhrif jarðvarmaklasans eru á nýsköpun fyrirtækja og iii. hver áhrif notkun jarðvarmans hefur á nýsköpun fyrirtækja.

Til pess að rannsaka petta viðfangsefni er farið pá leið að skoða tengingar aðstæðna við 
ákveðin raundæmi sem miðar að pví að lýsa stöðunni (e. exploratory). Í pví samhengi var ákveðið að nota raundæmisrannsókn sem byggir á fleiru en einu raundæmi (e. multiplecase studies) (Stake, 1995; Yin, 2003). Raundæmisrannsókn byggir jafnframt á túlkun rannsakenda á veruleikanum (e. constructivist paradigm) og gefur möguleika að pátttakendur segi söguna (Crabtree og Miller, 1999) út frá viðtölum og öðrum viðeigandi gögnum.

Í samhengi við rannsóknaraðferðina er mikilvægt að skoða nánar hvernig fyrirtæki sem tengd eru Auðlindagarðinum og jarðvarmaklasanum eru að nýta jarðvarmann með mismunandi hætti til nýsköpunar. Prjú fyrirtæki eru skoðuð með hliðsjón af nýsköpun og fjölpættum nýtingarmöguleikum jarðvarmans. Fyrirtækin eru: ORF Líftækni, Carbon Recycling International og Stolt Sea Farm Iceland. Fyrirtækin eru ólík að flestu leyti en eiga pað sameiginlegt að hagnýta jarðvarma og tengjast beint eða óbeint jarðvarmaklasanum og Auðlindagarðinum.

Greinin er skipulögð með eftirfarandi hætti, í kjölfar inngangsins er fræðilegur kafli sem fjallar um klasa, notendanýsköpun og notorku. Pá er kafli um aðferðafræði rannsóknarinnar sem byggir á raundæmisrannsókn. Raundæmunum ORF Líftækni, Carbon Recycling International og Stolt Sea Farm Iceland er lýst í stuttu máli og lokakaflinn snýr að niðurstöðum og umræðum.

\section{Fræðileg nálgun}

Í fræðilegum hluta greinarinnar er fjallað um klasafræðin í grófum dráttum og hvernig hugmyndir klasafræðinga hafa smám saman próast í pá átt að taka aukið mið af nýsköpun. Einnig er fjallað um nýsköpun út frá notendanýsköpun og loks eðli notorku. Tilgangur kaflans er að leiða umræðuna að meginpema greinarinnar, hvernig afmarkaður jarðvarmaklasi getur haft áhrif á próun nýsköpunar hjá fyrirtækjum sem tengjast klasanum.

\subsection{Klasar}

Talsvert hefur verið skrifað um tilvist klasa á undanförnum árum á Íslandi. Sem dæmi pá má finna fræðilega umfjöllun (t.d. Ívar Jónsson, 2002; Runólfur Smári Steinpórsson, 2010; Pór Sigfússon, 2013), greiningu á klösum (t.d. greining á: jarðvarmaklasanum (Hákon Gunnarsson og Póra Margrét Porgeirsdótir, 2011), sjávarklasanum (Vilhjálmur Jens Árnasón og Pór Sigfússon, 2011), upplýsingatæknigeiranum (Vilhjálmur Jens Árnason, 2013) og ferðapjónustuklasanum (Rósbjörg Jónsdóttir o.fl., 2013)) og umfjöllun stjórnvalda og stofnana um klasa (t.d. Iðnaðar- og viðskiptaráðuneytið, 1995, 2004; Stjórnarráð Íslands, 2010; Karl Friðriksson og Sævar Kristinsson, 2004; Elvar Knútur Valsson o.fl., 2013). Pessi mikli áhugi á klösum á Íslandi er að miklu leyti tengdur áhuga prófessors Michael Porters á jarðvarmanýtingu á Íslandi. Pað var fyrir tilstilli Porters að greining á jarðvarmaklasanum var gerð árið 2010 (Hákon Gunnarsson og Póra Margrét Porgeirsdótir, 2011). Porter er jafnframt einn mesti talsmaður klasahugsunar síðari ára og einn af leiðandi hugsuðum klasafræðanna (Guðjón Örn Sigurðsson og Runólfur Smári Steinpórsson, 2014).

Рað er hægt að skipta upp umræðunni um klasafræðin í nokkra flokka eftir fræðimönnum og nálgunum. Iðnaðarsvæði Alfreds Marshalls eru almennt álitin upphafspunktur umræðunnar. Marshall komst að pví að iðnaðarsvæði marka upphaf iðnbyltingarinnar (Marshall, 1890). Í Sheffield undir lok nítjánda áratugarins sá hann að iðnaðarmenn í ákveðnum greinum áttu í fullu tré við iðnvæddar verksmiðjur í Manchester, vöggu iðnbyltingarinnar (Caldari og Belussi, 2009; Bresci og Malerba, 2001). Greining Marshalls leiddi í ljós að hagkvæmni iðnaðarsvæða fælist í: a) færni sem erfist á milli kynslóða, b) tilkomu tengdra fyrirtækja sem sjá tækifæri í pyrpingarmyndun fyrirtækja, c) notkunar sérhæfðra framleiðslutækja vegna verkaskiptingar og sérhæfingar og d) framboði og eftirspurn á sérhæfðu vinnuafli fyrir staðbundna framleiðslu (Marshall, 1890 [1920]).

Раð er hins vegar sú fræðilega umræða um klasa sem hefur verið nefnd ítalski skólinn sem vakti meiri athygli á klasafræðunum en umfjöllun Marshalls. Upp úr 1970 sýndu 
rannsóknir Becattinis og hóps sem tengdist honum fram á að smáfyrirtæki gátu gegnt veigamiklu hlutverki í hagkerfinu við ákveðnar aðstæður (Becattini, 1990). Í bæjum eins og Modena, Empoli og Pesaro var afkoma fyrirtækja betri en víðast hvar á Ítalíu, kjör jafnari, störfum fjölgaði og smáfyrirtæki bæjanna urðu mörg hver öflug í útflutningi. Kjarni klasafræðanna er oft tengdur pessari umræðu, p.e. hvenær og hvernig lítil og meðalstór fyrirtæki próa náið samstarfsfyrirkomulag til að standast hnattvæðingu framleiðslunnar (Buciuni og Pisano, 2015). аð fyrirkomulag sem var einkennandi í Emilia Romagna var náið samstarf smáfyrirtækja sem unnu á sama sviði í pyrpingum og mynduðu klasa ekki ósvipað pví sem var að finna í Sheffield á öldinni áður sem var. Pessir stjórnarhættir voru í grundvallaratriðum ólíkir peim einkennum sem talin voru hornsteinn iðnvæðingarinnar, Fordisminn: fjöldaframleiðsla; aðskilnaður eignar og vinnu; tæknipróun og samhæft vinnulag par sem heildarútkoman var aukin framleiðni, ódýrari vörur sem pýddi að hægt var að greiða hærra kaup; p.e. ",aðskilnaður hugar og handar“ (Becattini, 1990). Fljótlega eftir að umræðan um klasana á Ítalíu varð almenn farið að kanna framleiðslufyrirkomulagið í stærra samhengi. Fyrirtæki keppa innbyrðis, t.d. um vörupantanir en sameinast pegar að framkvæmd kemur; pað er að eitt fyrirtæki sér um kaup á dýru tæki sem síðan er samnýtt, annað sérhæfir sig í ákveðnum aðföngum o.s.frv. Lykilpátturinn er sértæk fagpekking eða pað sem hefur verið nefnt sérhæfð fjölhæfni og pá á pví sviði sem gagnast klasanum í heild (Piore og Sabel, 1984). Sveigjanleikinn er pá lykilpáttur, að geta lagað framleiðsluna að sérstökum óskum kaupandans (Bahlman og Huysman, 2008). Fagpekking peirra og færni sem smíðuðu og próuðu framleiðslutækin væri allt eins mikilvæg og verksmiðjuframleiðslan sem slík.

Michael E. Porter gerði klasafyrirkomulagið að líkani eða greiningaraðferð par sem grunnskilgreiningin er svæðisbundin pyrping hagsmunatengdra fyrirtækja og stofnana á ákveðnu sviði (McDonald o.fl., 2007). Porter próaði klasahugtakið (e. cluster) pegar flestir höfðu notað iðnaðarsvæði eða iðnaðarhverfi í sínum skilgreiningum (Guðjón Örn Sigurðsson og Runólfur Smári Steinpórsson, 2014). Nálgun Porters á klasaumræðuna hefur að miklu leyti verið byggð á umræðu hans um samkeppnishæfni en demanturinn sem leitast við að útskýra samkeppnishæfni pjóða er dæmi um svæðisbundna samkeppnisyfirburði (Porter, 1990). Porter kynnti jafnframt hugmyndina um að pað væri mikilvægt að teikna upp og greina starfsemi klasa með pví að gera sérstakt klasakort (Porter, 1990). Klasakort hafa verið mikið notuð af stjórnvöldum pjóða til pess að ræða svæðisbundna stefnumörkun og byggðapróun. Hugmyndin um svæðisbundna próun felur í sér að klasarnir hafi aðdráttarafl fyrir fyrirtæki og fólk vegna efnahagslegs uppgangs sem á sér stað á svæðinu og bættum lífskjörum (Porter, 2008).

Klasar hafa einnig verið til umfjöllunar í tengslum við nýsköpunarumhverfi og vistkerfi (Bahlman og Huysman, 2008). Uppgangur Kísilsdalsins í Kaliforníu hefur að miklu leyti verið uppspretta peirrar umræðu. Rannsóknir Saxeninan (1994) bentu til pess að árangur í nýsköpun og framleiðslu í Kísildalnum mætti rekja til félagslegs tengslanet á milli fyrirtækja. Mikilvægi tengslanets fyrir nýsköpun hefur einnig verið stutt með rannsóknum á öðrum svæðum par sem pekking verður pá mikilvægasta auðlindin og lærdómur drifkraftur frampróunar (Maskel og Malmberg, 1999, Eineingerick o.fl., 2010, Asheim, 2018). Sérhæfðir klasar eru líklegir til pess að flýta fyrir og leiða til samstarf innan klasans sem ýtir undir tæknilega og samfélagslega nýsköpun (Asheim, 2018). Pví hefur jafnframt verið haldið fram að klasar geti pannig hjálpað stöðnuðum atvinnugreinum til að leggja áherslu á nýsköpun (Saha o.fl., 2018). Pekking og lærdómur verður pá jafnframt drifkraftur virkni og velgengi klasa og er ákveðin viðbót við pá umræðu um klasa sem Porter hefur staðið fyrir (Guðjón Örn Sigurðsson og Runólfur Smári Steinpórsson, 2014).

Eins og Porter bendir sjálfur á í skýrslunni sem kom út um kortlagningu jarðvarmaklasans að pá stendur jarðvarmaklasinn vart undir nafni t.d. vegna pess að pað er skortur á einkaleyfum og par með ekki skýrt eignarhald á mikilvægum framleiðslupáttum eins og túrbínum, rafölum og öðrum tækja-og vélbúnaði (Hákon Gunnarsson og Póra Mar- 
grét Porgeirsdótir, 2011). Klasakort jarðvarmaklasans gefur hins vegar áhugaverð mynd af tegundum fyrirtækja sem tengjast jarðvarmanum með einum eða öðrum hætti. Раð er ákveðinn pröskuldur fyrir notkun á jarðvarma sem frumorku að hann hentar ekki til raforkuframleiðslu á stórum skala. Hins vegar gefa fjölpættir nýtingarmöguleikar jarðvarmans möguleika á samstarfi í nýsköpun og fjármögnun tækifæra (Hákon Gunnarsson og Póra Margrét Porgeirsdótir, 2011).

Klasakort jarðvarmaklasans er skipt niður í kjarnastarfsemi og afleidda starfsemi eins og véla- og tækjaframleiðslu, pekkingu, sérfræðipjónustu, flutning og dreifingu til innlendra notenda sem nýta orku, gufu eða vatn með beinum eða óbeinum hætti. Beinir notendur eru hitaveita, iðnaður, fiskeldi og ylrækt og afpreying, heilsa og ferðapjónusta. Óbeinir notendur eru iðnaður og smásala á rafmagni (Hákon Gunnarsson og Póra Margrét Porgeirsdótir, 2011).

Sjálfbær og hagkvæm nýting auðlindar jarðvarmans felur í sér tækifæri fyrir nýsköpun og frumkvæði. Auðlindagarðurinn er dæmi um staðsetningu par sem ólíkir notendur safnast saman í kringum auðlindina með pað að markmiði að próa nýjar viðskiptahugmyndir og vörur (Gísli Hauksson, 2015).

Niðurstaða umræðu um klasa, og auðlindagarðinn sérstaklega, er að klasamyndun opnar á tækifæri til nýsköpunar. Lykilpættir í pví samhengi eru a) mikilvægi pekkingar og lærdómur sem drifkraftur frampróunar (Maskel og Malmberg, 1999, Eineingerick o.fl., 2010), b) sértæk fagpekking eða sérhæfð fjölhæfni (Piore og Sabel, 1984) og c) félagsleg tengsl á milli fyrirtækja í klasanum (Saxeninan, 1994). Pað er pörf á pví að rannsaka betur hvernig klasar geta haft áhrif á nýsköpun á fyrirtækja sem leiðir til samkeppnisyfirburða fyrirtækja og landa (Porter, 1990).

Í pessu samhengi er mikilvægt að athuga hvernig afmarkaður klasi eins og Auðlindagarðurinn getur haft áhrif á nýsköpun fyrirtækja. Spurningin er hvort að pað gerist vegna samsöfnunar pekkingar, próun á sérhæfðri fjölhæfni eða í gegnum tengslanet fyrirtækja, eða allt í senn.

\subsection{Nýsköpun og notendur}

Pað er ekki hægt að tala um nýsköpun án pess að minnast á Schumpeter (1934) í pví samhengi. Shumpeter (1934) hélt pví fram að nýsköpun væri drifkraftur efnahagslegra framfara og próun hagkerfa. Hann sagði að pessi frampróun gerðist með mismunandi hætti og nefndi fimm pætti í pví samhengi: 1) Nýjar vörur og ný útfærsla á pekktum vörum, 2) ný aðferðafræði við framleiðslu eða sölu á vörum og pjónustu, 3) nýr markaður sem varan eða pjónustan var ekki pekkt á, 4) notkun á nýrri uppsprettu auðlinda til framleiðslu og 5) nýtt skipulag atvinnugreinar sem t.d. annað hvort skapar eða eyðileggur einokunarstöðu. Tilgáta Schumpeters (1934) var að sá sem vildi skapa árangursríkan rekstur og hagnað pyrfti á nýsköpun að halda.

Uppspretta nýsköpunar er einnig að breytast með auknu samstarfi fyrirtækja og samstarfi fyrirtækja og einstaklinga. Opin nýsköpun er dæmi um hvernig margir aðilar koma að nýsköpunarferlinu óháð pví hvort peir tengist ákveðnu fyrirtæki eða ekki (Chesbrough, 2003). Opin nýsköpun hefur verið skilgreind sem aðferð par sem fyrirtæki geta nýtt sér inn- og útflæði pekkingar til pess að auka árangur í nýsköpun (Chesbrough og Bogers, 2014). Ferlið getur annars vegar verið innan úr og út úr fyrirtækinu sem gefur pá öðrum tækifæri til pess að nýta sér vannýttar hugmyndir sem tækifæri í próun á viðskiptahugmynd eða viðskiptamódeli. Á hinn bóginn er ferlið utan að og inn í fyrirtækið en pá nýtir fyrirtækið sér utanaðkomandi pekkingu og hugmyndir til pess að próa nýsköpun innan fyrirtækisins. Раð er pó aðallega síðari pátturinn sem hefur vakið mesta áhuga og athygli fræðimana (West og Bogers, 2013).

Notendadrifin nýsköpun er ekki ósvipuð hugmyndum um opna nýsköpun nema að pá eru pað viðskiptavinir eða notendur vörunnar sem eru uppspretta nýsköpunar (von Hip- 
pel, 2005). Notendadrifin nýsköpun er hugtak frá Eric Von Hippel (2005) og vísar til pess að notendurnir séu í auknum mæli í stöðu til að próa eða endurbæta pá vöru sem notuð er. Gerður er pá greinarmunur á tvennskonar notendum eða hópi notenda, peim sem nota tæki og tól í framleiðslu eða pjónustu (hefðbundin áframvinnsla) og par sem notandinn eða hópur notenda leggur til eða próar vöruna (von Hippel, 2005).

Рað má greina á milli priggja breyta sem eru lykilpættir í notendadrifnu nýsköpunarstarfi (von Hippel, 2005);

- Fyrirætlunar par sem notendur geta skilgreint og hafa innsýn í hverjar parfirnar eru.

- Færni par sem notendur eru færir um og hafa næga reynslu til að vinna verkið

- Staðhátta tækifæra par sem ytri aðstæður eru hagstæðar sem gera framkvæmdir mögulegar; tengslin á milli fyrirætlunar og forsendur til að vinna verkið.

Nýsköpun er yfirleitt flokkuð annað hvort sem róttæk (e. radical) eða smástíg (e. incremental) (Forés og Camisón, 2016). Mismunurinn snýst um hversu nýnæmið er mikið. Smástíg nýsköpun felur í sér nýja útfærslu á núverandi framboði sem fela í sér einungis smávægilegar breytingar en róttæk nýsköpun felur í sér próun á vöru og pjónustu sem felur í sér nýja tækni eða hugsun (McDermott og O’Connor, 2002). Róttæk nýsköpun felur yfirleitt í sér nýja tækni eða nýja upplifun fyrir viðskiptavini (Kelly o.fl., 2011). Jafnan kallar róttæk nýsköpun á meiri pörf fyrir hæfni og auðlindir en smástíg nýsköpun.

Niðurstaða umræðu um nýsköpun og notendur er að notendur á ákveðnum auðlindum, verkpáttum, vöru eða pjónustu geta fundið tækifæri til nýsköpunar í gegnum notkun, með pví að nýta, læra og betrumbæta pað sem er verið að nota. Рað er í sjálfu sér ekkert sem segir að petta geti ekki verið mismunandi útfærsla á nýsköpun, samanber Schumpeter (1934). Рað er í raun aðgengi að auðlindum, verkpáttum, vöru eða pjónustu, sem opnar tækifæri fyrir nýsköpun eins og pegar um opna nýsköpun ræðir (Chesbrough, 2003). Notendur purfa að geta skilgreint fyrirætlanir, hafa færni og geta nýtt sér staðhætti (von Hippel, 2005) til pess að geta nýtt sér tækifæri til nýsköpunar. Nýsköpun sjálf getur hvort sem er verið smástíg eða róttæk (Forés og Camisón, 2016) sem ræðst annars vegar af tækifærinu og hins vegar hæfninni sem fyrir er, eins og Penrose (1985) benti á.

Í pessu samhengi er mikilvægt að athuga hvernig nýsköpun verður til hjá fyrirtækjum og hvort að notkun á auðlind geti haft áhrif á pá nýsköpun. Spurningin er hvort að fyrirtækin séu að nýta sér aðstöðuna og hafi bæði fyrirætlanir og hæfni til pess að nýta sér jarðvarma og Auðlindagarðinn sem uppsprettu nýsköpunar.

\subsection{Eiginleikar jarðvarmans, takmarkanir og tækifæri}

Hvað jarðvarma og hagnýtingu hans varðar pá er pað hvorki afurðin né framleiðslutækin sem sem eru í lykilhlutverki heldur felst virði hans í notkunarsamhenginu. Blá lónið dregur að sér ferðamenn og pað er hvorki orkan sem slík né orkuverið sem myndar lónið sem hefur aðdráttaraflið heldur sundstaðurinn sem er einn af arðbærustu fyrirtækjum landsins. Stolt Farm er staðsett á Reykjanesi vegna sérstæðrar samsetningar á heitu vatni og saltvatni eða efnasamsetningu pess (Gísli Hauksson, 2015). Nýting á jarðvarma má annars vegar flokka sem frumorku og notorku.

Frumorka felur pað í sér pegar jarðvarmaorku er breytt í rafmagn eða einsleita orku, pað sem einkennir nýtingu raforku annars vegar og hins vegar milliliðalausa nýtingu á heitu vatni. Í tilfelli raforku hefur dreifikerfið meginpýðingu. Staðlað og áreiðanlegt kerfi gerir mönnum kleift að nota fjöldaframleidd tæki sem byggjast á stöðluðum viðmiðum (t.d. rafspennu sem er ákvörðuð 220 vött í Evrópu). Ólíkt raforkunni er sú orka sem berst til hins endanlega notanda ekki alltaf eins. Pannig verður að gaumgæfa mun betur að aðstæðum og notkunarstaðsetningu og tilgangi. Til dæmis er efnasamsetningin mismunandi 
og stundum getur verið erfitt að hafa stjórn á henni og hún getur leitt til tæringar í dreifingarkerfinu.

Рað hefur skipt sköpum fyrir daglegt líf hér á landi að flytja heitt vatn beint til notenda í stað pess að breyta pví í staðlaða orku. Samhengisbundin nýting verður lykilatriði; með pví að sameina prjá pætti, verklega færni, dulda og kerfisbundna pekkingu. Pegar pjóna parf sífellt fleiri tjáđum pörfum koma í ljós fjölmörg tækifæri og oft óvæntir möguleikar. Î nýsköpunarfræðum er gerður greinarmunur á prenns konar lærdómsferlum: verklegri færni, undirliggjandi (e. tacit) pekkingu og formlegri pekkingu (Nonaka og Takeuchi, 1995). Мeð verklegri færni er átt við athafnalærdóm eða færni sem markast af pjálfun, undirliggjandi pekkingu, fagkunnáttu. Formlegri eða kerfisbundinni pekkingu er á hinn bóginn hægt að miðla skriflega og pannig getur hún orðið kjarninn í vísindalegu starfi (Nielsen og Nielsen, 2009).

Í tilfelli jarðvarmans er lykilatriði að færa áhersluna frá auðlind til notkunar. Fyrir utan húshitun og sundlaugar er heita vatnið notað á margvíslegan og ólíkan hátt og hefur bæði víðtækar félagshagfræðilegar og menningarlegar afleiðingar. Til dæmis framleiðsla matvæla eins og grænmeti- og ávaxta í gróðurhúsum og fiskeldi, framleiðsla á vissum heilsuvörum og framleiðsla eldsneyti fyrir bíla. Að ganga út frá viðeigandi tækni í pessu samhengi er að festa sig ekki í aðgreiningunni á milli óendurnýtanlegra og endurnýtanlegra kosta, heldur að átta sig á pví hvernig mismunandi náttúruleg ferli henta mismunandi markmiðum. Að nýta eiginleika heita vatnsins sem notorku á sér langa sögu víða um heim en jafn víðtæk og almenn notkun pess og tíðkast hérlendis á sér ekki hliðstæðu (Hákon Gunnarsson og Póra Margrét Porgeirsdótir, 2011).

Í pessu samhengi er mikilvægt að reyna að draga fram hvernig auðlindin er nýtt og hvort að hún byggir á verklegri færni eða fomlegri pekkingu. Spurningin er hvort og hvernig notkorkan leiðir til nýsköpunar hjá fyrirtækjum.

\section{Aðferðafræði}

Viðfangsefni rannsóknarinnar býður upp á nokkrar leiðir hvað varðar aðferðafræði sem geta verið eigindlega, megindlegar eða samsettar. Aðferðafræði verður að taka mið af aðstæðum og tilgangi rannsóknarinnar. Í ljósi pess að ekki hefur verið skrifað mikið um viðfangsefnið pá var ályktað að pað væri mikilvægt að byggja rannsóknina á raundæmum (e. case study) (Stake, 1995; Yin, 2003). Raundæmisrannsókn byggir á túlkun rannsakenda á veruleikanum (e. constructivist paradigm) og gefur möguleika á að pátttakendur segi söguna (Crabtree og Miller, 1999). Yin (2003) lagði áherslu á að raundæmisögur sem aðferðafræði væru áhugaverður kostur pegar: a) áhersla rannsóknarinnar er á „hvernig“ og „af hverju“ spurningar; b) að ekki er hægt að hafa áhrif á hegðun peira sem eru til rannsóknar; c) að mikilvægt er að taka tillit til ytri aðstæðna par sem peir pættir hafa áhrif á viðfangsefnið sem verið er að skoða; eða d) skilmörkin á milli viðfangsefnisins og ytri aðstæðna eru ekki með öllu skýr. Aðferðafræðin hefur verið m.a. notuð til pess að meta ákvarðanatökur og hvaða pættir hafa áhrif á ákvarðanir (Baxter, 2006).

Viðfangsefnið í pessari rannsókn eru fyrirtæki í ákveðnu samhengi klasa, sem er í samræmi við tillögur Baxter og Jack (2008) um notkun aðferðafræðinnar. Rannsóknarspurningin felur í sér ákveðna óvissu og pað er viðfangsefni rannsóknarinnar að draga fram ólíkar nálganir fyrirtækja út frá svipuðum útgangspunkti. Viðfangsefni rannsóknarinnar verða hins vegar að vera skorðuð með ákveðnum hætti til pess að skerpa á aðferðafræðinni (Yin, 2003; Stake, 1995; Creswell, 2003; Miles og Huberman, 1994) t.d.: a) stað og stund, b) tíma og aðgerð og c) skilgreiningu og aðstæðum. Með pví að skorða viðfangsefnið er hægt að halda utan um umfang verkefnisins (Baxter og Jack, 2008). Í pessari rannsókn eru öll raundæmin tengd í gegnum aðstæður sem er annars vegar staðsetning í Auðlindagarðinum á Reykjanesi og hins vegar út frá notkun auðlinda jarðvarmans.

Ennfremur er mikilvægt að ákveða tegund rannsóknar, hvort að henni sé gert að spá fyrir um, útskýra, skoða og greina eða lýsa viðfangsefni (Yin, 2003). Í pessu tilviki er verið 
að skoða hver tenging aðstæðna er við ólík raundæmi (e. exploratory) og jafnframt draga lærdóm af ólíkum raundæmum (e. multiple-case studies). Tilgangur pess að hafa fleiri en eitt raundæmi er að bera saman pað sem líkt og ólíkt í mismunandi sögum en tilgangurinn er pá annað hvort að: a) meta svipaðar niðurstöður eða b) ólíkar niðurstöður (Yin, 2003). Раð er petta innsæi sem raundæmi geta gefið (Baxter og Jack, 2008) sem gera aðferðafræðina áhugaverða í tilviki pessarar rannsóknar par sem ekki er ljóst hvert ólík raundæmi leiða.

Raundæmisrannsókn parf að: a) fela í sér tilgátu, jafnvel pó hún sé ekki skýrt skilgreind, b) ramma sem verið er að vinna eftir, c) próun á rannsóknarspurningum, sem að jafnaði snúast um „hvernig“ og/eða „,af hverju“, d) tengingu gagna við tilgátu og e) aðferðafræði við túlkun gagna (Yin, 2003; Miles og Huberman, 1994; Baxter og Jack, 2008). Eftirfarandi umræða gefur nánari útskýringar á hvaða raundæmi er verið að nota og hvernig og pá með tilliti til hvernig raundæmin eru notuð sem rannsóknaraðferð.

\subsection{Tilgangur og val á raundæmum}

Tilgangur með raundæmum í pessari rannsókn er að varpa ljósi á pað hvernig aðstæður og tengingar við aðstæður, p.e. Auðlindagarðinn, hafa haft áhrif á nýsköpun og viðskiptapróun ólíkra fyrirtækja. Með pessi viðmið að leiðarljósi voru prjár mismunandi raundæmisögur valdar sem voru líklegar til pess að segja ólíka sögu en jafnframt tengja sögurnar við uppruna og aðstæður. Fleiri sögur voru hafðar í huga en féllu á prófum hvað varðar: a) nýsköpun, b) tengingu við Auðlindagarðinn, og c) aðgengi að gögnum. Lögð var áhersla á prjú fyrirtæki sem raundæmisögur: Orf líftækni, Carbon Recycling International og Stolt Sea Farm.

\subsection{Gagnaöflun}

Árið 2015 gerði Gamma ráðgjöf skýrslu fyrir Auðlindagarðinn með pað markmið að skoða fjölpætta nýtingu jarðvarma á Reykjanesskaga (Gísli Hauksson, 2015). Pessi skýrsla var ákveðinn útgangspunktur til pess að meta hvaða raundæmi gætu verið áhugaverð í pví samhengi sem rannsóknin miðast við. Gagnaöflun var tvípætt, annars vegar notkun skráðra gagna og hins vegar djúpviðtöl.

Skráð gögn eru skýrslur, heimasíður, fréttagreinar og sjónvarpsefni sem tengjast viðfangsefninu. Nokkrar skýrslur hafa verið skrifaðar um mikilvægi jarðvarmans á Íslandi, jarðvarmaklasann og Auðlindagarðinn. Heimasíður félagana gefa mynd af sögu félaganna og greinar og sjónvarpsefni gefa aðeins dýpri innsýn í starfsemi félaganna. Engu að síður eru skráð gögn mjög takmörkuð hvað varðar innsýn og greiningu á nýsköpun félaganna og tenginu við Auðlindagarðinn. Til pess að fá innsýn í hvaða gögn eru til var haft samband við forsvarsmenn Jarðvarmaklasans og Auðlindagarðsins.

Viðtöl voru tekin við lykilaðila hjá fyrirtækjum til pess að fá betri mynd af viðfangsefni rannsóknarinnar. Ýmist voru tekin hópviðtöl eða djúpviðtöl með formlegu en sveigjanlegu sniði (e. semi-structured interview) sem felst í pví að hafa ákveðinn spurningagrunn en spyrja síðan í framhaldinu fleiri spurninga sem miða að pví að fá betri upplýsingar. Viðmælendur sýndu jafnframt myndir og vörur til pess að styðja mál sitt og gefa meira lýsandi mynd af vörum og ferlum sem voru til umræðu. Hjá Orf Líftækni var tekið viðtal við einn af stofnendum félagsins sem hefur jafnframt verið framkvæmdastjóri og leiðir nú viðskiptapróun félagsins. Hjá Carbon Recycling International var tekið hópviðtal við markaðsstjóra og tvo lykilaðila úr viðskiptapróunardeild félagsins. Hjá Stolt Sea Farm var tekið viðtal við einn af lykilaðilum í uppsetningu og frampróun verkefnsins. 


\subsection{Spurningar og greining}

Grunnur fyrir spurningar var byggður á fræðilegri umfjöllun um klasa, notendanýsköpun og umræðu um jarðvarmaorku. Spurningaramminn fólst í fimm spurningum:

Hver er viðskiptahugmyndin sem er grunnur fyrirtækisins?

Í hverju felst verðmætasköpun fyrir viðskiptavininn?

Í hverju felst nýsköpunin?

Hvaða áhrif/tilgang hefur auðlindagarðurinn/jarðvarmaklasinn á fyrirtækið?

Hver er notkun jarðvarmans/heita vatnsins og hvaða áhrif hefur pað á fyrirtækið?

Pessar spurningar voru pó einungis ramminn sem notaður var í viðtölum par sem mikið af spurningum vöknuðu pegar umræðan fór í gang. Engu að síður var ramminn mikilvægur til pess að halda viðtalendum við efnið og sem einskonar tékklisti yfir pað sem nauðsynlegt væri að fá útúr hverju viðtali.

Viðtölin voru flokkuð og greind útfrá spurningum og viðfangsefni rannsóknarinnar og borin saman við raundæmin. Leitað var eftir lykilorðum og fundnir umræðupættir sem voru lýsandi og áhugaverðir í pví samhengi sem rannsóknin var gerð. Rannsakendur ræddu svo sérstaklega hvert viðtal fyrir sig og gerðu grein fyrir hvernig peir túlkuðu pað sem sagt var.

\subsection{Umgjörð á raundæmisögum}

Skipulag og framsetning á raundæmum miðast við að halda sögupræðinum í tengslum við rannsóknina. Рað eru í sjálfu sér margar leiðir til pess að setja fram raundæmisögur en með tilliti til útgáfu og áherslna var ákveðið að reyna að draga saman lykilatriði í hverju tilviki fyrir sig frekar en að hafa mjög ítarlega framsetningu á hverri raundæmisögu. Raundæmin eru líka sett fram með peim hætti að sú fyrsta er ítarlegust og svo er leitað við að setja pann hluta af öðrum raundæmum sem bætir einhverju við fyrstu raundæmisöguna. Hver raundæmisaga hefur pó sömu kaflaskiptingu:

1. Stutt saga félagsins

2. Viðskiptahugmynd og nýsköpun

3. Áhrif auðlinda og pyrpingar

Fyrsti hlutinn segir sögu félagsins í mjög stuttu máli með pað að markamiði að setja söguna í samhengi. Sagan er sögð eins og birtist á skráðu efni og hvernig stjórnendur sögðu hana í viðtölum. Annar pátturinn er viðskiptahugmynd og nýsköpun en par er reynd að gera grein fyrir í hverju viðskiptahugmyndin er fólgin eins og henni er lýst af stjórnendum og hvernig hún hefur hugsanlega breyst frá stofnun. Einnig er reynt að draga fram lykilpætti sem varða nýsköpun félagsins. Í priðja hlutanum er fjallað um hvernig aðstæður hafa haft áhrif á próun félagsins, pá sérstaklega Auðlindagarðurinn og Jarðvarmaklasinn. Niðurstöður af raundæmunum premur eru svo skoðaðar sérstaklega.

\section{Raundæmin}

Prjú raundæmi eru notuð í pessari rannsókn: Orf Líftækni, Carbon Recycling International og Stolt Sea Farm. Raundæmin voru valin vegna pess að pau segja mismunandi sögur um viðfangsefni rannsóknarinnar og voru líklegar til pess að gefa innsýn sem var ekki áður augljós. Allar raundæmisögurnar eru skipulagðar með sama hætti, p.e.: Saga félagsins í hnotskurn, Viðskiptahugmyndin og verðmæti, Nýsköpunin og próun viðskiptahugmyndar og Áhrif auðlinda og pyrpingar. Raundæmisögurnar eru sambland af notkun skráðra upplýsinga og viðtala. 


\subsection{Orf Líftækni}

\subsubsection{Stutt saga félagsins}

ORF Lífækni var stofnað árið 2001. Stofnendurnir prír höfðu pá pegar unnið að rannsóknum tengdum viðskiptahugmyndinni í um tíu ár. Félagið er í grunninn líftæknifyrirtæki sem sérhæfir sig í framleiðslu og sölu á vaxtarpáttum úr mönnum fyrir læknisfræðirannsóknir. Árið 2008 byggði ORF gróðurhús í Auðlindagarðinum í Grindavík. Upphafleg stærð gróðurhússins var $2.000 \mathrm{~m} 2$ par sem lagt var upp með að rækta um 130.000 byggplöntur par sem vaxtarpættirnir voru framleiddir. Pessa vaxtarpætti átti að selja til rannsóknarstofnana og lyfjafyrirtækja sem myndu nota pá í rannsóknum og próun á lyfjum og heilsuvörum. Í dag eru fyrirtækið að selja vaxtarhormón til 25 fyrirtækja. Í kringum árið 2006 var hins vegar orðið ljóst að pessi vegferð yrði lengri en áætlað var og аð pað væri erfitt að keppa við pá stóru aðila sem fyrir voru á markaðinum. •að var pví ákveðið að skjóta fleiri stoðum undir fyrirtækið og sú fyrsta var að selja vaxtarpætti fyrir húðvörur. ORF gat framleitt um 6-8 vaxtarpætti sem höfðu áhrif á húðina. Prátt fyrir mikla eftirspurn og áhuga í kjölfar vörusýningar í Bandaríkjunum árið 2008 ákváðu stjórnendur félagsins að hætta við að selja öðrum aðilum vaxtarpættina vegna pess að pað var ljóst að pað væri ekki einfalt fyrir starfandi félög að nýta vaxtarpættina eins og best væri kostur og myndu pá sennilega nota pá að nafninu til sem myndi grafa undan ímynd vaxtarpátta sem mikilvægu efni í húðvörur. Par af leiðandi var tekin ákvörðun í ársbyrjun 2009 um að ORF líftækni myndi sjálft framleiða og selja húðvörur undir vörumerkinu BIOEFFECT. Pegar varan var fyrst markaðssett á Íslandi var hún einnig seld undir sérstöku íslensku vörumerki, EGF húðdropar, en er nú einungis fáanlegt undir vörumerkinu BIOEFFECT. Framleiðsla og sala á húðvörum er undir fyrrnefndu vörumerki. Salan er alpjóðleg og hefur snúist um að finna dreifileiðir sem eru nær lúxusenda markaðarins, pað pýðir verslanakjarnar eins og Harrods í Bretlandi og Harvey Nichols í Hong-Kong og flugfélög eins og British Airwaves, KLM og Jar. BIOEFFECT er nú selt á 28 markaðssvæðum og eru nýjustu markaðirnir Bandaríkin og Kína, sem mikil von er bundin við. Hingað til hefur vöxturinn verið hraður eða um 25\% - 30\% á ári og velti félagið um 1,6 milljörðum króna árið 2018. Framtíðarsýn stjórnenda ORF Líftækni er skjóta fleiri stoðum undir reksturinn en eins og er pá fer allur tími starfsmanna í próun, framleiðslu og sölu á húðvörum.

\subsubsection{Viðskiptahugmyndin og nýsköpun}

Sú viðskiptahugmynd sem ORF Líftækni byggir á núna er talsvert önnur en sú sem sem lagt var af stað með upphaflega. Segja má að ORF Líftækni sé fyrst og fremst fyrirtæki sem sérhæfir sig í húðvörum og uppbyggingu á vörumerki. Vaxtapættir leika enn lykilhlutverk en minna hlutverk en áður par sem pað er frekar hönnunarhugsun en vísindi sem eru útganspúnktur í markaðssetningu á vörum félagsins. Petta má t.d. sjá með pví að skoða kynningarbæklinga og vörur félagsins. Í pví samhengi má benda á að nýjustu vörur félagsins, sem eru til pess gerðar að félagið hafi fulla vörulínu fyrir viðskiptavini sína, hafa ekkert með vaxtarpætti að gera. Nýtt hreinsiefni byggir á notkun vikurs og húðhreinsir vörulínunnar leggur áherslu á íslenska vatnið. Pannig hefur próun vörumerkisins BIOEFFECT tekið yfir upprunanlegan tilgang félagsins og áherslu á vaxtarpætti. Í raun eru pað fjórir pættir sem notaður eru í markaðssetningu: 1. Vísindin, 2. Virkni vörunnar, 3. Hreinleikinn og einfaldleikinn og 4. Staðsetningin á Islandi. Hins vegar snýst framtíðarsýn félagsins eftir sem áður að nota próun vaxtarpátta til pess að byggja fleiri stoðir undir félagið.

ORF Líftækni er nýsköpunarfyrirtæki. Hugmyndin að próa mannlega vaxtarpætti í byggfrumum var nýstárleg í alpjóðlegu samhengi. ORF er jafnframt eina fyrirtækið í heiminum sem hefur próað og komið upp alpjóðu vörumerki sem byggir á plöntutækni á neytendamarkaði. Pessi vörupróun er líka einstök í íslensku samhengi og ORF er jafnframt eina fyrirtækið sem framleiðir húðvörur að öllu leyti á Íslandi. 


\subsection{3 Áhrif auðlinda og pyrpingar}

Pegar stjórnendur ORF Líftækni voru að skoða aðstöðu fyrir gróðurhús félagsins voru prír aðalkostir til skoðunar. Grindavík varð hins vegar fyrir valinu aðallega vegna peirrar hugmyndafræði sem Auðlindagarðurinn stóð fyrir, p.e. að búa til framleiðslu og nýsköpun sem byggir á grænni orku og sjálfbærni. Gróðurhús ORF Líftækni fékk heitið Græna smiðjan og hefur leikið mikilvægt hlutverk í að skapa ímynd félagsins. Stjórnendur félagsins hafa hug á að byggja ennfrekar upp Grænu smiðjuna sem markaðstæki með pví að búa til betri aðstöðu fyrir ferðamenn og viðskiptavini að sækja félagið heim í Grindavík. Ísland, eiginleikar vatnsins, hreinleiki og lágt kolefnafótspor hafa jafnframt verið notað í markaðssetnum á BIOEFFECT vörum fyrirtækisins.

Viðskiptamódel félagsins byggir jafnframt á pví að hægt sé að framleiða vaxtarpættina með hagkvæmum hætti. Rannsóknir félagsins á aðstöðu annars staðar í heiminum benda til pess að pað sé erfitt að finna hagkvæmari kost fyrir slíka framleiðslu en núverandi aðstæður. Rafmagnskostnaður skiptir par miklu máli, en ekki síður aðgengi að hreinu köldu vatni en pað parf mikil af köldu vatni í ræktun. Ennfremur leikur heita vatnið hlutverk í upphitun og kalda veðrið á Íslandi gegnir hlutverki í að halda hitanum niðri, rétt eins og í tilviki gagnavera á Íslandi.

Stjórnendur ORF Líftækni hafa takmörkuð samskipti við aðra aðila innan Auðlindagarðsins eða jarðvarmaklasans. Að einhverju leyti fylgjast peir með og hafa rætt um hvernig samstarfið við HS - Orku gæti próast frekar, t.d. hvað varðar notkun koltvísýrings.

\subsection{Carbon Recycling International}

\subsubsection{Stutt saga félagsins}

Carbon Recycling International (CRI) var stofnað árið 2006 af tveimur íslendingum og tveimur útlendingum. Stofnendur félagsins höfðu pá pegar unnið að rannsóknum sem voru grundvöllur fyrirtækisins. Félagið er nýsköpunarfyrirtæki sem nýtir fjölda ólíkra auðlindastrauma jarðvarmaversins í Svartsengi til pess að framleiða metanól. Árið 2012 hóf CRI rekstur verksmiðju í Auðlindagarðinum í Grindavík. Framleiðslugeta verksmiðjunnar var upphaflega um 1,5 milljón lítrar af metanóli á ári en var svo stækkuð í fimm milljón lítra. Stefnan var að metanólið yrði notað sem eldsneyti á farartæki og sem íblöndun í bensín. Heimamarkaðurinn fyrir metanól er hins vegar mjög lítill og fáar stöðvar par sem hægt er að fá blandað bensín. Par af leiðandi var ljóst að upprunalega viðskiptahugmyndin var óraunhæf. Áherslu félagsins fór í auknum mæli að próast út í verkefnamiðaða starfsemi sem miðast við heildarlausnir á metanól-verksmiðjum (e. turnkey projects). Fyrirtækið hefur verið að hanna og próa verksmiðjur erlendis undanfarin ár. Stærsta verkefnið er í Noregi sem felst í framleiðslu á 50.000 tonnum. En verkefnin eru í auknum mæli að verða alpjóðleg og árið 2017 opnaði CRI skrifstofu í Shanghai til pess að greiða leið inn á Kínamarkað. Fyrsta verkefnið var samningur um verksmiðju fyrir efnaframleiðandann Henan Shuncheng Group sumarið 2019.

\subsubsection{Viðskiptahugmynd og nýsköpun}

Carbon Recycling International framleiðir hreint vistvænt metanól undir vörumerkinu Vulcanol. Nýsköpunin felst í aðferðafræði við að framleiða metanól á stórum skala úr koltvísýringi (CO2) sem er einskonar úrgangur pegar jarðvarmi er nýttur sem orkugjafi. Metanólið flokkast sem endurnýjanleg orka en heimilt er að blanda allt að 3\% af metanóli í bensín sem selt er á Evrópska efnahagssvæðinu. Framleiddir eru bílar sem geta verið knúnir metanóli eingöngu og einnig bílar með sérstaka bensínhreyfla sem geta notað hærra hlutfall metanóls en hefðbundnar bifreiðar.

Allt sem tengist breytingum í umhverfismálum hefur verið að sækja sig á en aðferðafræði CRI snýst um að draga úr koltvísýringi, eyða úrgangi og auka hagkvæmni. Tækni CRI getur fangað koltvísýring frá iðnaði og raforkuvinnslu eins og kolaverksmiðjun, stál- 
verksmiðjum og ammoníakverksmiðjum. Hakvæmni CRI snýst að miklu leyti um gæði kotvísýringsins en hann er t.d. mjög góður í tilviki HS-Orku. Рað sem gerir pað að verkum að viðskiptavinir hafa áhuga á lausnum CRI er að með peim hætti geta peir verið umhverfisvænir. Pá er einnig ljóst að stjórnvöld hafa í auknum mæli farið að vera hliðholl umhverfisvænum lausnum og styrkt slíka starfsemi.

Starfsmenn CRI eru mjög virkir í að leita að nýjum lausnum sem hægt er að framleiða með pví að vinna úr koltvísýring og hafa peir verið að skoða nýjungar í eldsneyti sem verið er að prófa í Kína. En pröskuldurinn í framleiðslunni er alltaf skalanleikinn, pað er eitt að framleiða á tilraunastofu en pað er talsvert annað að framleiða nægilega mikið magn að pað verði hagkvæm framleiðsla.

Pegar ljóst var að sala á metanóli var minni en áætlanir gerðu ráð fyrir fór félagið í auknu mæli að skoða sölu á hugviti með pví að vinna að uppsetningu á verksmiðjum fyrir erlenda aðila sem vilja framleiða metanól úr vetni, raforku og koltvísýringi og sama tíma draga úr mengun. CRI á einkaleyfi vegna tækninnar sem notuð er í Svartsengi og önnur tengd einkaleyfi sem gerir рað auðveldara að selja heildarlausnir erlendis. Stefna félagsins er að setja upp prjátíu verksmiðjur í Evrópu og Kína fyrir árið 2030.

\subsection{3 Áhrif auðlinda og pyrpingar}

Eðli málsins samkvæmt var pað alltaf stefnan að byggja verksmiðju í Auðlindagarðinum par sem hugmyndin var að nýta affallið af framleiðslu HS-Orku. Hugmyndin er að einhverju leyti rakin til Alberts Albertssonar hjá HS-Orku sem er hugmyndafræðingur Auðlindagarðsins. Hugmyndin var að gera eitthvað verðmætt úr úrgangi. Verksmiðjan fær jarðhitagas sem er blanda koltvísýrings (CO2 ) og brennisteinsvetnis (H2S) frá jarðvarmaverinu. Eftir að brennisteinsvetnið hefur verið hreinsað úr jarðhitagasinu er koltvísýringurinn blandaður vetni sem fengið er með pví að kljúfa vatn upp í vetni og súrefni með rafgreiningu og fer gasblandan par næst í gegnum efnaferli sem myndar metanól. Pó að framleiðslan hafi verið aukin úr 1,6 milljón lítrum í 5 lítra á ári árið 2015, pá eru uppi hugmyndir um að hægt sé að gera framleiðsluna ennpá stærri og ná hugsanlega tíföldun á núverandi framleiðslu ef hreinsa mætti koltvísýringinn frá jarðvarmaverinu betur. Рað væri framleiðsla fyrir erlendan markað og myndi gera kröfu um hagkvæman flutning.

Núverandi viðskiptahugmynd CRI byggir frekar á að framleiða verksmiðjur fyrir aðila erlendis frekar en að framleiða meira metanól hér á landi til útflutnings. Aðstaðan í Svartsengi gegnir mjög mikilvægu hlutverki í markaðsstarfi á heildarlausnum enda er hægt að sýna viðskiptavinum hvernig til hefur tekist á Íslandi. Рað hefur hjálpað að skapa ákveðna ímynd og athygli að fyrirtækið er staðsett á Íslandi og vörumerkið Vulcanol hefur verið notað til pess að undirstrika upprunann á Íslandi.

Stjórnendur CRI hafa takmörkuð samskipti við aðra aðila innan Auðlindagarðsins eða jarðvarmaklasans og eru ekki formlega hluti af klasanum. Samstarfið við HS-Orku hefur pó verið farsælt. Samstarfið við Jarðvarmaklasann hefur að mestu snúist um aðstoð við að hafa áhrif á stjórnvöld og sveitarfélög en stjórnendur jafnframt fylgst með vinnu klasans eins og kostur er.

\subsection{Stolt Sea Farm}

\subsubsection{Stutt saga félagsins}

Stolt Sea Farm Iceland var stofnað árið 2012. Fyrirtækið er dótturfyrirtæki Stolt-Nielsen Limited sem er í eigu spænska félagsins Stolt Sea Farm, sem stofnað var árið 1972. Félagið er fiskeldisfyrirtæki sem byggir á hátækni og rannsóknum á próun líffræði, fóðurs og lífvenja sjávardýra. Stöðin sem var byggð í Auðlindagarðinum í Grindavík er hönnuð fyrir eldi á 2.000 tonnum á ári en afkastageta í fyrsta áfanga var um 500 tonn. Í stöðinni er lögð áhersla á framleiðslu á Senegalflúru til útflutnings en flúran er hágæðaflatfiskur. Flúran er flutt frá Íslandi óunnin. 


\subsubsection{Viðskiptahugmynd og nýsköpun}

Viðskiptahugmynd Stolt Sea Farm Iceland snýst um að framleiða hágæða fisk á hagkvæman hátt á Íslandi og selja hann til hæstbjóðenda erlendis. Nýsköpunin felst fyrst og fremst í framleiðsluferlinu sem nýtir blöndun á köldum og heitum sjó til pess að ná kjörhitastigi fyrir eldið á mjög hagkvæman hátt.

\subsection{3 Áhrif auðlinda og pyrpingar}

Staðsetning fiskeldis Stolt Sea Farm Iceland í Auðlindagarðinum var fyrst og fremst fólgin í hagkvæmni, jafnvel pó að framleiðslan yrði flutt úr landi. Ódýrt rafmagn og aðgengi að köldu vatni spilaði stórt hlutverk en pað sem vekur mesta athygli er hvernig fiskeldið hefur nýtt sér sjóinn sem jarðvarmaverið notar til pess að kæla eimsvala hverfla versins. Pannig er sjór úr borholum sem síaður er í gegnum hraunlög og hækkar úr 8-9 gráðum á Celsíus í 35 gráður við að kæla eimsvalana notaður í fiskeldið. Fiskeldið blandar volga sjóinn með síuðum köldum borholusjó og fær við pað eldissjó við kjörhitastig fisksins. Hreinn sjór við kjörhitastig sem hentar fiskeldinu árið um kring er sérstaða sem eykur öryggi, hagkvæmni og afkastagetu hjá félaginu.

Stjórnendur Stolt Sea Farm Iceland hafa takmörkuð samskipti við aðra aðila innan Auðlindagarðsins en HS-Orku og eru ekki formlega hluti af jarðvarmaklasanum.

\section{Umræður}

Til pess að rannsaka hvernig afmarkaður jarðvarmaklasi getur haft áhrif á próun nýsköpunar hjá fyrirtækjum var stuðst við raundæmisrannsókn og prjú raundæmi skoðuð; ORF Líftækni, Carbon Recycling International og Stolt Sea Farm Iceland. Ennfremur er leitað svara við pví hjá fyrirtækjunum; i. í hverju nýsköpunin felst, ii. hver áhrif jarðvarmaklasans eru á nýsköpun fyrirtækja og iii. hver áhrif notkun jarðvarmans hefur á nýsköpun fyrirtækja.

Stjórnendum ORF Líftækni, Carbon Recycling International og Stolt Sea Farm Iceland hefur öllum tekist að búa til fyrirtæki sem byggja frampróun á nýsköpun. ORF Líftækni próaði vaxtarpætti sem ræktaðir eru í byggplöntum í Grænu smiðjunni í Auðlindagarðinum en nýttu svo vaxtarpættina til pess að próa húðvörur undir vöruheitinu BIOEFFECT. Próun og markaðssetning á húðvörum byggir svo í auknum mæli á ímynd hreinleika, sjálfbærni og upprunanum á Íslandi. Carbon Recycling International varð til í tengslum við hugmyndafræði Auðlindagarðsins, að nýta pað sem fellur frá við orkuvinnslu. Nálægðin við HS-Orku var lykilpáttur. Viðskiptahugmyndin hefur hins vegar próast út í ráðgjafarvinnu og verkefnavinnu í formi heildarlausna sem nýtir sér verksmiðjuna í Svartsengi sem dæmi um hvað hægt er að gera á öðrum stöðum í metanólframleiðslu. Stolt Sea Farm Iceland hefur próað ferla og aðferðafræði til pess að rækta hágæðaflatfisk fyrir erlendan markað og er stöðugt að endubæta ferlið og skoða framleiðslumöguleika.

Öll fyrirtækin hafa próað nýsköpun í smáum skrefum (Forés og Camisón, 2016) og tvö af fyrirtækjunum, p.e. ORF Líftækni og Carbon Recycling International hafa próast talsvert frá upphaflegu viðskiptahugmyndinni pó að í henni felist enn ákveðin kjarnastarfsemi. Með pví að próa viðskiptahugmyndina með pað að markmiði að skapa félögunum rekstrargrundvöll hefur tekist að finna syllu á markaðnum, hvort sem er fyrir skilvirkar einfaldar húðvörur eða heildarlausn við uppsetningu á metanólverksmiðju, sem hefur skapað pessum félögum nýja framtíðarsýn. Î báđum pessum tilvikum er minni pörf fyrir upprunann í jarðvarmaklasanum en áđur út frá nýtingu á jarðvarma en að einhverju leyti meiri áhersla á pörfina fyrir sterka ímynd í markaðssetningu.

Út frá hugmyndum um notendanýsköpun (von Hippel, 2005) má segja að fyrirætlun ORF Líftækni, Carbon Recycling International og Stolt Sea Farm Iceland hafi verið skýr. Í öllum tilvikum var færnin jafnframt til staðar, par sem viðskiptahugmyndir voru í öllum tilvikum byggðar á talsverðu rannsóknar og próunarstarfi. Frumkvöðlarnir voru vísindamenn sem pekktu ferlið mjög vel pó að peir hafi hugsanlega ekki verið sérfræðingar í 
viðskiptamódelum og rekstri fyrirtækja. Stolt Sea Farm Iceland byggir starfsemi sína á áratuga reynslu í fiskeldi en parf að nýta sér aðstæður til pess að ná peirri hagkvæmni sem nauðsynleg er fyrir reksturinn. Staðhættir skipta par að leiðandi miklu máli og pað er færnin sem ræður pví hvernig tækifæri ytri aðstæðna eru nýtt til nýsköpunar og próunar. Staðhættir voru í öllum tilvikum mikilvægir út frá sjálfbærum, vistvænum orkugjafa og í öllum tilvikum tókst að búa til ferla og skipulag sem gerði framleiðslu pessara priggja fyrirtækja mögulega. Раð voru hins vegar markaðsaðstæður sem gerðu pað að verkum að pörf var á að endurskoða viðskiptamódel félaganna, sérstaklega í tilviki ORF Líftækni og Carbon Recycling International. Staðhættir skiptu pó máli eftir sem áður pó með tilliti til peirrar ímyndar sem peir bjóða upp á frekar en orkugjafa.

Klasafræðin hafa próast með pað að leiðarljósi að nálægð og samvinna er grundvöllur fyrir árangri fyrirtækja (Marshall, 1890; Piore og Sabel 1984; Becattini, 1990; Porter, 1990). Pekkingaryfirflæði og lærdómur er jafnframt grundvöllur frampróunar klasa og nýsköpunar (Maskel og Malmberg, 1999, Eineingerick o.fl., 2010). Рað vekur athygli að ekkert peirra priggja fyrirtækja sem eru skoðuð í pessari grein hafa sérstaklega mikil samskipti við samfélag jarðvarmaklasans eða Auðlindagarðsins. Engin kerfisbundin yfirfærsla pekkingar og hugmynda á sér stað. Engu að síður hafa öll pessi félög próast og skapað nýjungar í eigin krafti og hafa nýtt sér staðhætti til pess að skapa hagkvæman rekstur og próa og prófa lausnir og til pess að markaðssetja sig á erlendum mörkuðum. Рað er erfitt að meta hvort að árangurinn hefði verið meiri ef yfirflæði pekkingar í klasanum og Auðlindagarðinum hefði verið meiri en raun ber vitni en út frá kenningum klasafræðinnar mætti ætla að tækifæri glatist pegar pekking og lærdómur ólíkra fyrirtækja klasans er ekki nýtt (Maskel og Malmberg, 1999).

Einn mikilvægur páttur í vexti klasans er að draga að erlend fyrirtæki (Hákon Gunnarsson og Póra Margrét Porgeirsdótir, 2011) sem geta nýtt sér aðstæður og notað færni og fyrirætlanir til pess að skapa hagkvæman rekstur (von Hippel, 2015). Stolt Sea Farm Iceland er dæmi um slíkt fyrirtæki. Pað eru hins vegar fáir sem pekkja rekstur félagsins og af hverju pað getur skapað arðsaman rekstur með pví að rækta erlendan fisk og flytja hann úr landi og selja. Fyrirtækið ætti að vera kærkomið dæmi um hvers konar félög gætu flutt í Auðlindagarðinn og skapað árangursríkan rekstur.

Umræðan um jarðvarma á Íslandi hefur fyrst og fremst snúist um frumorku, og að flytja heitt vatn til notenda. Раð eru hins vegar fjölmörg tækifæri sem felast í notorku. Eins og tilviki ORF Líftækni, Carbon Recycling International og Stolt Sea Farm Iceland, pá hefur notorkan viðtæk áhrif í framleiðslu á hágæða fiskafurðum, einstökum húðvörum og umhverfisvænu metanóli fyrir farartæki. Í öllum tilvikum hefur líka viðskiptahugmyndin orðið að vöru í sjálfu sér pó að Carbon Recycling International sé komið lengst með pví að selja heildarlausn um uppbyggingu á verksmiðjum á öðrum stöðum í heiminum. Dæmin sýna hvernig nýta má notorku með fjölbreyttum hætti til pess að skapa hagkvæman rekstur, nýjungar í vörum og pjónustu og ný viðskiptamódel. ORF Líftækni hefur skapað nýja vöru með nýja eiginleika og nýja aðferðafræði við framleiðslu og sölu á vöru með pví að tengja saman eiginleika vörunnar og ímynd. Að uppspretta framleiðslu á húðvörum sé að finna í gróðurhúsi sem byggir á nýtingu jarðvarma er einnig nýstárlegt. Carbon Recycling International hefur próað nýja aðferðaferða í framleiðslu á metanóli og notkun á nýrri uppsprettu auðlindar sem byggir á jarðvarma. Einnig má segja að heildarlausnin sem felst í að setja upp umhverfisvæna metanólverksmiðju sé nýstárleg, í peirri atvinnugrein sem félagið er, bæði sem pjónusta og viðskiptamódel. Loks hefur Stolt Sea Farm Iceland framleitt vöru með nýjum hætti og í krafti uppsprettu jarðvarmans sem ekki hefur verið notuð í pessu samhengi áđur. Рað má pví segja að nýsköpun pessara priggja fyrirtækja sem öll byrjuðu starfsemi sína í tengslum við að nýta jarðvarmann sé all nokkur.

Niðurstaðan er аð pað er margt sem bendir til pess að afmarkaður jarðvarmaklasi geti haft áhrif á próun nýsköpunar hjá fyrirtækjum. Í peim premur raundæmum sem skoðuð eru í pessari rannsókn hefur nýsköpun eitthvað að sækja í jarðvarmann og klasann. Раð 
mætti jafnvel færa rök fyrir pví að pessi fyrirtæki hefðu ekki farið pá leið í nýsköpun sem raun ber vitni ef pau hefðu ekki verið hluti af sérhæfðum jarðvarmaklasa, samanber rannsóknir á sérhæfðum klösum (Asheim, 2018). Rannsóknin bendir til pess að ástæðan sé fyrst og fremst í próun á sérhæfðri fjölhæfni (Piore og Sabel, 1984) og samansöfnunar pekkingar (Maskel og Malmberg, 1999, Eineingerick o.fl., 2010). Рað eru hins vegar færri vísbendingar um að tengslanetið skipti máli (Saxeninan, 1994). Pvert á móti virðist pað sameiginleg niðurstaða stjórnenda fyrirtækjanna að áhersla á tengslanet innan klasans skiptir minna máli. Má segja að pað sé talsvert í mótsögn við pað sem fræðimenn telja vera meginávinning klasa (Saxeninan, 1994, Porter, 2008). Petta misræmi kallar á frekari rannsóknir par sem lögð er áhersla að skilja annars vegar eðli tengslaneta innan klasa og hins vegar hvernig slíku tengslaneti er stýrt.

Pessi rannsókn var lýsandi (e. exploratory) og leitaðist við að skoða áhugavert viðfangsefni sem hefur verið lítið rannsakað. Pörf er fyrir frekari rannsóknir á sérhæfðum klösum sem gefur mynd af pví hvernig peir geta haft áhrif á nýsköpun fyrirtækja. Рað er jafnframt pörf fyrir frekari rannsóknir á pví hvernig jarðvarminn getur leitt til mismunandi nýsköpunar notorku og hvernig áhrif jarðvarmans á Íslandi og jafnvel ímyndar um hreinleika landsins hefur áhrif á ímynd fyrirtækja. Orf líftækni væri áhugavert í pví samhengi, sem og Bláa lónið.

\section{Heimildir}

Asheim, B. T. (2018). Smart specialisation, innovation policy and regional innovation systems: what about new path development in less innovative regions?. Innovation: The European Journal of Social Science Research, 32:1.

Auðlindagarðurinn. (2019). Saga Auðlindagarðsins. www.audlindagardur.is

Bahlmann, M. D. og Huysman, M. H. (2008). The emergence of a knowledge-based view of clusters and its implications for cluster governance. The Information Society, 24(5), 304-318.

Banbury, C.M. and Mitchell, W. (1995), “The effect of introducing important incremental innovations on market share and business survival", Strategic Management Journal, Vol. 16 No. S1, pp. 161-182.

Bathelt, H., Malmberg, A., og Maskell, P. (2004). Clusters and knowledge: local buzz, global pipelines and the process of knowledge creation. Progress in Human Geography, 28(1), 31-56.

Baxter, P., \& Rideout, L. (2006). Decision making of 2nd year baccalaureate nursing students. Journal of Nursing Education, 45(4), 121-128.

Becattini, G. (1990). ‘The Marshallian Industrial District as a Socio-Economic Notion'. Í Pyke, F. og Sengenberger, W. (Ritstj.) Industrial Districts and Local Economic Regeneration (37-51). Geneva: International Institute for Labour Studies.

Birch, David L., "The Job Generation Process," unpublished report (Washington, DC: MIT Program on Neighborhood and Regional Change for the Economic Development Administration, U.S.Department of Commerce, 1979)

Bláa lónið. (2018). Ársskýrsla 2017. Sótt á heimasíðu félagsins 20. mars 2019.

Bresci, S. og Malerba, F. (2001). The Geography of Innovation and Economic Clustering: Some Introductory Notes. Industrial and corporate change, Oxford University Press

Caldari, K og Belussi, F. (2009). At the origin of the industrial district: Alfred Marshall and the Cambridge school. Cambridge Journal of Economics, Volume 33, Issue 2, March 2009, Pages 335-355,

Chesbrough, H.W. (2003). Open Innovation: The New Imperative for Creating and Profiting from Technology. Harvard Business Press.

Crabtree, B. og Miller, W. (1999). Doing qualitative research (2nd ed.). London: Sage.

Creswell, J. (1998). Research design: Qualitative, quantitative, and mixed methods approaches (2nd ed.). Thousand Oaks, CA: Sage.

Eisingerich, A. B., Bell, S. J. og Tracey, P. (2010). How can clusters sustain performance? The role of network strength, network openness, and environmental uncertainty. Research Policy, 39(2), 239-253.

Elvar Knútur Valsson, Karl Friðriksson, Runólfur Smári Steinpórsson, Sigurður Steingrímsson og Sandra Brá Jóhannsdóttir. (2013). Klasar: Handbók um próun klasa. Í Berglind Hallgrímsdóttir (Ritstj.). Reykjavík: Nýsköpunarmiðstöð Íslands.

Forés, B. and Camisón, C. (2016). “Does incremental and radical innovation performance depend on different types of knowledge accumulation capabilities and organizational size?", Journal of Business Research, 69(2), 831-848.

Hagstofa Íslands (2019). Fiskeldi á Íslandi. Sótt 12. desember 2020 af https://www.hagstofa.is/utgafur/frettasafn/ sjavarutvegur/fiskeldi-a-islandi/ 
Hákon Gunnarsson og Póra Margrét Porgeirsdóttir. (2011). Virðisauki i jarðvarma. Íslenski jarðvarmaklasinn; Vegferð og vegvísir. Reykjavík: Gekon ehf.

Giulio Buciuni og Gary P. Pisano. (2015). Can Marshall's Clusters Survive Globalization? Working Paper 15-088 Harvard Business School

Gísli Hauksson. (2015). Auðlindagarðurinn. Fjölpætt nýting jarðvarma á Reykjanesskaga. Reykjavík: GAMMA ráðgö̈f.

Gordon, I. R., og McCann, P. (2000). Industrial clusters: complexes, agglomeration and/or social networks?. Urban studies, 37(3), 513-532.

Guðjón Örn Sigurðsson og Runólfur Smári Steinpórsson. (2014). Klasar og klasakenningar. Erindi flutt á Vorráðstefnu Viðskiptafræðistofnunar Háskóla Íslands í mars 2014. Reykjavík: Viðskiptafræðistofnun Háskóla Íslands.

Iðnaðarráðuneytið. (1995). Tengsl iðnaðar og sjávarútvegs. Skýrsla nefndar. Iðnaðar- og viðskiptaráðuneyti, rit 95-5. Reykjavík: Iðnaðar- og viðskiptaráðuneyti.

Iðnaðar- og viðskiptaráðuneyti. (2004). Vaxtarsamningur Eyjafjarðarsvæðis: til aukinnar samkeppnishæfni, sóknar og alpjóðatengsla. Tillögur Verkefnisstjórnar um byggðaáætlun fyrir Eyjafjarðarsvæðið, rit 04-1. Reykjavík: Iðnaðar- og viðskiptaráðuneyti.

Ívar Jónsson. (2002). Nýsköpun og svæðisbundnir fyrirtækjaklasar. Research Paper Series No4. Biffröst School of Business. Sótt 20. mars 2019 af http://www.bifrost.is/Files/Skra_0000944.pdf.

Karl Friðriksson og Sævar Kristinsson. (2004). Klasar - Samstarfí samkeppni. Reykjavík: Iðntæknistofnun.

Kelley, D.J., O'Connor, G.C., Neck, H. and Peters, L. (2011), “Building an organizational capability for radical innovation: the direct managerial role", Journal of Engineering and Technology Management, 28(4), 249-267.

Malmberg, A., \& Maskell, P. (1997). Towards an explanation of regional specialization and industry agglomeration. European planning studies, 5(1), 25-41.

Malmberg, A., og Maskell, P. (2002). The elusive concept of localization economies: towards a knowledgebased theory of spatial clustering. Environment and planning A, 34(3), 429-450.

Malmberg, A., og Maskell, P. (2006). Localized learning revisited. Growth and Change, 37(1), 1-18.

Markusen, A. (2003). Fuzzy concepts, scanty evidence, policy distance: the case for rigour and policy relevance in critical regional studies. Regional Studies, 37(6-7), 701-717.

Marshall, A. (1920). Principles of economics. London: MacMillan

Maskell, P., og Malmberg, A. (1999). Localised learning and industrial competitiveness. Cambridge Journal of Economics, 23(2), 167-185.

McDermott, C.M. and O'Connor, G.C. (2002), "Managing radical innovation: an overview of emergent strategy issues", Journal of Product Innovation Management, 19(6), 424-438.

McDonald, F., Huang, Q., Tsagdis, D., og Josef Tüselmann, H. (2007). Is there evidence to support Porter-type cluster policies?. Regional Studies, 41(1), 39-49.

Miles, M. B., \& Huberman, A. M. (1994). Qualitative data analysis: An expanded source book (2nd ed.). Thousand Oaks, CA: Sage.

Nielsen, B. B., and Nielsen, S. (2009). “Learning and Innovation in International Strategic Alliances: An Empirical Test of the Role of Trust and Tacitness." Journal of Management Studies 46 (6): 1031-1056.

Nonaka, I., and Takeuchi, H. (1995). The Knowledge Creating Company. Oxford: Oxford University Press

Penrose, E. (1985). 'The theory of the growth of the firm twenty-five years after'. Uppsala: Acta

Universitatis Upsaliensis, Studia Oeconomiae Negotiorum 2

Piore, M. J. and Sabel, Ch. F. (1984). The Second Industrial Divide: Possibilities for Prosperity. New York: Basic Books.

Porter, M. E. (1990). The Competitive Advantage of Nations. Macmillan, London.

Porter, M. E. (2000). Location, competition, and economic development: Local clusters in a global economy. Economic Development Quarterly, 14(1), 15-34.

Rósbjörg Jónsdóttir, Friðfinnur Hermannsson, Hákon Gunnarsson, Sigurjón Pórðarson og Vilborg H Júlíusdóttir. (2013). Kortlagning og samstarfsmótun íslenskrar ferðapjónustu: Virðisauki í ferðapjónustu. Reykjavík: Gekon ehf.

Saha, N., Sáha, T., and Sáha, P. (2018) Cluster strategies and smart specialisation strategy: do they really leverage on knowledge and innovation-driven territorial growth? Technology Analysis and Strategic Management $10 / 4$.

Schumpeter, J.A. (1934). TheTheory of Economic Development: An Inquiry into Profits, Capital, Credit, Interest, and the Business Cycle, Harvard University Press, Cambridge, MA.

Saxenian, A. (1994). Regional advantage: Culture and competition in Silicon Valley and Route 128. Cambridge, Massachusetts: Harvard University Press.

Stake, R. E. (1995). The art of case study research. Thousand Oaks, CA: Sage.

Stjórnarráð Íslands. (2010). 20/20 sóknaráætlun: Niðurstöđur 20/20 Sóknaráætlunar. Tekið saman af stýrihópi 20/20 Sóknaáætlunar. Reykjavík: Stjórnarráo Íslands.

Storper, M. og Scott, A. (1988). The geographical foundations and social regulation of flexible production complexes. Í Wolch, J. og Dear M. (Ritstj.) Territory and Social Reproduction. London: Allen \& Unwin.

Vilhjálmur Jens Árnason og Pór Sigfússon. (2011). Íslenski sjávarklasinn: Skýrsla um umsvif, tækifæri og áskoranir. 
Reykjavík: Sjávarklasinn

Vilhjálmur Jens Árnason. (2013). Efling samstarfs útflutningsfyrirtækja í hugbúnaðariðnaði með klasa hugmyndafræði. Reykjavík: Íslandsstofa. Sótt 20. Mars 2019 af http://issuu.com/islandsstofa/docs/www.islandsstofa. is.

Von Hippel, E. (2005). Democratizing Innovation. Cambridge: The MIT Press.

Pór Sigfússon. (2013). The Relationship Networks of Entrepreneurs and the Effects of a Formation of an Industry Cluster on Their Relationships. Business and Management Research 2(1), 104-115.

West, J. and Bogers, M. (2013). “Leveraging External Sources of Innovation: A Review of Research on Open Innovation," Journal of Product Innovation Management, 31(4): 814-831.

Yin, R. K. (2003). Case study research: Design and methods (3rd ed.). Thousand Oaks, CA: Sage. 
